\title{
Association Between the Methicillin Resistance of Staphylococcus aureus Isolated from Slaughter Poultry, Their Toxin Gene Profiles and Prophage Patterns
}

\author{
Agnieszka Marek ${ }^{1} \cdot$ Ewelina Pyzik $^{1} \cdot$ Dagmara Stępień-Pyśniak $^{1} \cdot$ Renata Urban-Chmiel $^{1} \cdot$ Łukasz S. Jarosz $^{2}$
}

Received: 17 December 2017 / Accepted: 24 May 2018 / Published online: 29 May 2018

(c) The Author(s) 2018

\begin{abstract}
In this work, 85 strains of Staphylococcus aureus were isolated from samples taken from slaughter poultry in Poland. Attempts were made to determine the prophage profile of the strains and to investigate the presence in their genome of genes responsible for the production of five classical enterotoxins (A-E), toxic shock syndrome toxin (TSST-1), exfoliative toxins (ETA and ETB) and staphylokinase (SAK). For this purpose, multiplex PCR was performed using primer-specific pairs for targeted genes. The presence of the mecA gene was found in 26 strains (30.6\%). The genomes of one of the methicillinresistant $S$. aureus (MRSA) strains and two methicillin-sensitive $S$. aureus (MSSA) strains contained the gene responsible for the production of enterotoxin A. Only one MRSA strain and two MSSA strains showed the presence of the toxic shock syndrome toxin ( $t s t$ ) gene. Only one of the MSSA strains had the gene (eta) responsible for the production of exfoliative toxins A. The presence of the staphylokinase gene ( $s a k$ ) was confirmed in 13 MRSA strains and in 5 MSSA strains. The study results indicated a high prevalence of prophages among the test isolates of Staphylococcus aureus. In all, 15 prophage patterns were observed among the isolates. The presence of 77-like prophages incorporated into bacterial genome was especially often demonstrated. Various authors emphasize the special role of these prophages in the spread of virulence factors (staphylokinase, enterotoxin A) not only within strains of the same species but also between species and even types of bacteria.
\end{abstract}

\section{Introduction}

Staphylococcus aureus has the ability to induce severe diseases of animals and humans, that are associated with numerous virulence factors produced by these bacteria, such as toxins, cell adhesins and secreted exoproteins (coagulase, toxic shock syndrome toxin-1, staphylokinase and others) [1-5]. Staphylococcal enterotoxins (SEs) and toxic shock syndrome toxin-1 (TSST-1) are exotoxins that belong to the

Electronic supplementary material The online version of this article (https://doi.org/10.1007/s00284-018-1518-9) contains supplementary material, which is available to authorized users.

Agnieszka Marek

agnieszka.marek@up.lublin.pl

1 Sub-Department of Preventive Veterinary and Avian Diseases, Institute of Biological Bases of Animal Diseases, Faculty of Veterinary Medicine, University of Life Sciences in Lublin, Akademicka 13, 20-950 Lublin, Poland

2 Department of Epizootiology and Clinic of Infectious Diseases, Faculty of Veterinary Medicine, University of Life Sciences in Lublin, Głęboka 30, 20-612 Lublin, Poland superantigen family $[6,7]$. The mechanism of action of superantigens involves the ability to induce non-specific stimulation of T lymphocyte proliferation and cytokine secretion. The accumulation of cytokines in the mammalian body can lead to toxic shock. Another consequence of the presence of enterotoxins in the body is their enterotoxicity, resulting in food poisoning. A single bacterial strain may produce any of these toxins separately or in various combinations $[2,8]$.

Staphylokinase (SAK) a protein produced by certain $S$. aureus strains is a fibrin-specific activator of human plasminogen. During the infection process, staphylokinase disrupts phagocytosis of bacterial cells, and fibrinolysin, a component of staphylokinase, facilitates the penetration of staphylococci into tissues and their proteolytic degradation [9]. The ability of $S$. aureus strains to produce staphylokinase can be exploited to trace the ecological origin of a strain. It has been observed that $S$. aureus strains of human biotype can produce enterotoxins much more frequently than strains of animal biotypes. However, some researchers claim that strains derived from poultry are also capable of producing this protein [3]. 
Mobile genetic elements (MGEs), such as bacteriophages, plasmids, pathogenicity islands, transposons or insertion sequences, encode putative virulence factors and molecules that confer the ability to produce enterotoxins, TSST-1, exfoliative toxins or staphylokinase [10-13]. The vast majority of bacteria contain prophages integrated into their chromosome or as extra-chromosomal elements. Detection of staphylococcal prophages by multiplex PCR is comparable in sensitivity to detection by hybridization of restriction fragments [14]. A key role in the pathogenesis and virulence of the S. aureus is attributed to temperate bacteriophages of the Siphoviridae family belonging to the order Caudovirales. Based on their lytic activity, morphology and serological properties, phages of the Siphoviridae family are classified into six phage types: $3 \mathrm{~A}$-like virus, 11-like virus, 77-like virus and 187-like virus. Phages of type 77-like fall into two serological subgroups, $\mathrm{Fa}$ and $\mathrm{Fb}$, which can be present at the same time as prophages in the genome of bacteria [15]. Phages of the Twort-like type are related to lytic phages and belong to the family Myoviridae. Bacteriophages, via lysogenic conversion and participation in the spread of pathogenic islands, are believed to contribute to $S$. aureus variability and the formation of highly virulent strains [16]. They can also influence the adaptation of $S$. aureus to its hosts, both human and domesticated animals, by providing new genetic information or facilitating the loss of unnecessary DNA in the new ecological niche. It has been demonstrated that $S$. aureus strains of animal origin may be susceptible to the same bacteriophages as human strains, and thus via phage they can acquire the virulence factors characteristic for human strains [11].

Despite efforts to reduce the use of antibiotics in poultry production in the past few years, there has been a steady increase in the incidence of bacterial infections with multiple-resistant strains of Staphylococcus species in poultry flocks. There has also been an enormous increase in the number of methicillin-resistant (MRSA) strains [17, 18]. Resistance to beta-lactam antibiotics is usually dependent on the presence of the mecA gene, which encodes the lowaffinity penicillin-binding protein (PBP)-designated $\mathrm{PBP} 2 \mathrm{a}$ and makes the staphylococci resistant to almost all antibiotics of this group (penicillins, almost all cephalosporins and carbapenems), of which many are still widely used in both human and veterinary medicine $[19,20]$. The presence of virulence factors and antibiotic resistance genes in isolates of $S$. aureus indicates the risk carried by a particular strain.

The objective of this study was to determine the prevalence of methicillin-resistant (MRSA) and methicillinsensitive $S$. aureus (MSSA) in samples taken from chicken and turkey broilers in Poland, and the associations between the methicillin resistance of $S$. aureus strains isolated from poultry, their toxin gene profiles and their ability to produce staphylokinase. Because the vast majority of
S. aureus contain prophages integrated into their chromosome, their prophage patterns were identified as well. Gene polymorphism of twenty-six MRSA isolates by Pulsed-field gel electrophoresis (PFGE) with restriction enzymes SmaI and ApaI was performed as well.

\section{Methods}

\section{Sample Collection}

The study was conducted on material derived from broiler chickens and turkeys farms located in the area of centralwestern Poland between December 2013 and November 2015. During this time, samples from 153 flocks were collected. Randomly selected birds showing clinical signs of disease from each flock were examined. Three to five specimens from the affected organs were taken from each bird. A total of 569 samples from broilers and 446 samples from turkeys were collected. The samples were taken from internal organs (heart, liver, tarsal joints and bone marrow) of birds aged 1 day to 6 weeks (chickens) or 20 weeks (turkeys). The samples were taken from birds showing the following clinical symptoms: increased mortality, dermatitis and cellulitis, lameness and arthritis, decreased weight gain and omphalitis and yolk sac infections. The size of the flocks from which the samples were collected ranged from 8000 to 44000 birds.

The material collected (samples of internal organs) was plated on a blood agar medium (Blood LAB-AGAR, Biocorp, Poland) and Chapman selective medium (Mannitol Salt LAB-AGAR, Biocorp, Poland) and incubated under aerobic conditions at $37^{\circ} \mathrm{C}$ for $24-48 \mathrm{~h}$, depending on the rate of growth of the bacteria. Single colonies were transferred to blood agar in order to isolate pure bacterial cultures and a preliminary bacteriological characterization was made of the isolated flora, involving Gram's staining, cell morphology and motility using microscope and type of haemolysis. In this study, quantitative measurement of the colony was not performed.

Isolated bacteria were stored for further testing at $-85^{\circ} \mathrm{C}$ in $50 \%(\mathrm{v} / \mathrm{v})$ glycerol in brain heart infusion broth (BHIB; Sigma).

\section{Statement of Human and Animal Rights}

All procedures performed in studies involving human participants were in accordance with the ethical standards of the institutional and/or national research committee and with the 1964 Helsinki Declaration and its later amendments or comparable ethical standards. 


\section{Characterization of Bacterial Strains}

The identification of all Staphylococcus strains was carried out using mass spectrometry MALDI-TOF MS using the IVD MALDI Biotyper (Bruker Daltonik, Bremen, Germany) as described by Marek et al. [21].

The susceptibility of 11 antibiotics was tested using standard disc diffusion method on Mueller-Hinton agar plates (CM0337B, Oxoid, UK) using a bacterial suspension with the turbidity adjusted to a $0.5 \mathrm{McF}$ arland standard. The susceptibility of bacteria was determined for the following agents (Oxoid, England): amoxicillin $25 \mu \mathrm{g}$ (AML25); amoxicillin + clavulanic acid 20 + $10 \mu \mathrm{g}$ (AMC30); ampicillin $10 \mu \mathrm{g}$ (AMP10); penicillin G 10 units (P10); cefoxitin $30 \mu \mathrm{g}$ (FOX30); clindamycin $2 \mu \mathrm{g}$ (DA2); chloramphenicol $30 \mu \mathrm{g}$ (C30); erythromycin $15 \mu \mathrm{g}$ (E15); gentamicin $10 \mu \mathrm{g}$ (CN10); tetracycline $30 \mu \mathrm{g}$ (TE30); trimethoprim-sulphamethoxazole 1:19, $25 \mu \mathrm{g}$ (SXT25). The categories susceptible, intermediate resistant or resistant were assigned on the basis of the Guidelines for Susceptibility Testing [20]. The Minimum Inhibitory Concentrations (MIC) for oxacillin were additionally evaluated by the broth microdilution method [20]. For oxacillin, S. aureus strains showing MIC of $\geq 4 \mu \mathrm{g} / \mathrm{ml}$ were determined to be MRSA. For quality control, S. aureus ATCC 25923, Escherichia coli ATCC 25922 and E. faecalis ATCC 29212 were used in the microdilution tests.

\section{Bacterial DNA Extraction}

Total DNA was extracted from the collected strains inoculated individually on blood agar and incubated at $37^{\circ} \mathrm{C} / 24 \mathrm{~h}$. The Novabeads Bacterial DNA kit (Novazym Poland) was used for DNA extraction according to the manufacturer's protocol.

\section{Detection of the mecA Gene}

The identification of all MRSA isolates was confirmed by multiplex PCR (set A) targeting the mecA gene encoding methicillin resistance. To verify the efficiency of the amplification, an internal control primer pair targeting an S. aureusspecific nис region was amplified. PCR for mecA and nис gene was carried out by the methodology described by Brakstad et al. and Murakami et al. [18, 22]. Isolates of $S$. aureus that were mecA and nuc positive were considered as MRSA.

\section{Prevalence of Toxins and sak Genes in S. aureus and MRSA Isolates}

A multiplex PCR assay for detection of genes for staphylococcal enterotoxins A to E (sea, seb, sec, sed and see)-set $\mathrm{B}$, and for toxic shock syndrome toxin $1(t s t)$ and exfoliative toxins A and B (eta and $e t b)$ - set C, was developed using eight pairs of primers (Table 1). The conditions of the multiplex PCR reaction were taken from the study by Mehrota et al. [23].The PCR primers used to amplify the sak gene are listed in Table 1. The conditions of the PCR reaction were taken from the study by Sung et al. [24].

\section{Multiplex PCR for Detection of Prophages in S. aureus Strains}

A multiplex PCR assay (set D) for detection of DNA sequences specific for 3A-like, 11-like, 77-like, 187-like and Twort-like phages was developed using eight pairs of primers (Table 2). The conditions of the multiplex PCR reaction were taken from the study by Pantůček et al. [31].

\section{Pulsed-field Gel Electrophoresis (PFGE)}

The genetic relatedness of MRSA isolates was investigated by PFGE of total DNA digested with SmaI or ApaI restriction endonucleases [32]. S. aureus non-typeable with SmaI were subjected to ApaI-PFGE and run for $20 \mathrm{~h}$ at $6 \mathrm{~V} / \mathrm{cm}$ using pulsed time ranging from 2 to $5 \mathrm{~s}$. The SmaI or ApaI fragments were electrophoretically separated in a $1 \%(\mathrm{w} / \mathrm{v})$ agarose (Sigma-Aldrich, Poland) gel using the CHEF Mapper System (BIO-RAD, Poland). The macrorestriction patterns were examined by cluster analysis using NTSYSpc ver. 2.02 software (Exeter Software Ltd, USA). The similarity distances between pulsotypes (PFGE patterns) were calculated using the Dice coefficient, and the dendrogram was based on the unweighted pair group method with arithmetic average (UPGMA). According to the criteria proposed by Tenover et al., isolates whose PFGE pattern differed in more than six restriction fragments (bands) were genetically unrelated and were assigned to different pulsotypes, named as Arabic letters. Isolates were considered to be related if their pulsotype differed in no more than six restriction bands (subtype) and were indicated with the major lettering type followed by a number [33]. SmaI- and ApaI-generated pulsotypes were distinguished by capital- and lower-case Arabic letters, respectively.

\section{Results}

\section{Sample Collection}

A total of 567 bacterial strains belonging to the genus Staphylococcus were isolated from the material tested. The Staphylococcus strains isolated from the samples belonged to 24 species. Among 24 Staphylococcus species, 85 strains of $S$. aureus were identified. The remaining strains belonged to the species S. cohnii (27.7\%), S. lentus (17\%), S. chromogenes 
Table 1 Nucleotide sequences and sizes of PCR products of methicillin resistance, thermonuclease, enterotoxins (A-E), TSST-1, exfoliative toxins and staphylokinase

\begin{tabular}{|c|c|c|c|c|c|}
\hline Primer* & Oligonucleotide sequence $\left(5^{\prime}-3^{\prime}\right)^{* *}$ & Gene & $\begin{array}{l}\text { Size of ampli- } \\
\text { fied product } \\
\text { (bp) }\end{array}$ & Control strain & References \\
\hline NUC-1 & GCGATTGATGGTGATACGGTT & nис & 270 & ATCC43300 & {$[22]$} \\
\hline NUC- & AGCCAAGCCTTGACGAACTAAAGC & & & & \\
\hline MEC-1 & AAAATCGATGGTAAAGGTTGGC & mecA & 533 & & {$[18]$} \\
\hline MEC-2 & AGTTCTGGCACTACCGGATTTGC & & & & \\
\hline ESA1 & ACGATCAATTTTTACAGC & sea & 544 & FRI913 & {$[10]$} \\
\hline ESA2 & TGCATGTTTTCAGAGTTAATC & & & & \\
\hline ESB1 & GAATGATATTAATTCGCATC & $s e b$ & 416 & ATCC13566 & {$[25]$} \\
\hline ESB2 & TCTTTGTCGTAAGATAAACTTC & & & & \\
\hline ESC1 & GACATAAAAGCTAGGAATTT & $\sec$ & 257 & FRI913 & {$[10]$} \\
\hline ESC2 & AAATCGGATTAACATTATCCA & & & & \\
\hline ESD1 & TTACTAGTTTGGTAATATCTCCTT & sed & 334 & FRI151m & [26] \\
\hline ESD2 & CCACCATAACAATTAATGC & & & & \\
\hline ESE1 & ATAGATAAAGTTAAAACAAGCAA & see & 170 & FRI913 & {$[27]$} \\
\hline ESE2 & TAACTTACCGTGGACCC & & & & \\
\hline GTSSTR-1 & ACCCCTGTTCCCTTATCATC & tst & 326 & FRI1169 & [28] \\
\hline GTSSTR-2 & TTTTCAGTATTTGTAACGCC & & & & \\
\hline GETAR-1 & GCAGGTGTTGATTTAGCATT & eta & 93 & CCM7056 & [29] \\
\hline GETAR-2 & AGATGTCCCTATTTTTGCTG & & & & \\
\hline GETBR-1 & ACAAGCAAAAGAATACAGCG & $e t b$ & 226 & CCM7056 & [29] \\
\hline GETBR-2 & GTTTTTGGCTGCTTCTCTTG & & & & \\
\hline SAK-1 & TGAGGTAAGTGCATCAAGTTCA & sak & 403 & ATCC25923 & {$[30]$} \\
\hline SAK-2 & CCTTTGTAATTAAGTTGAATCCAGG & & & & \\
\hline
\end{tabular}

*The sets of primers were synthesized by Genomed S.A, Poland

**The concentration of primers was $0.04 \mu \mathrm{mol}$

Table 2 Multiplex PCR ${ }^{*}$. Primer sequence of staphylococcal phage type, PCR product length and type of protein

\begin{tabular}{|c|c|c|c|c|}
\hline Phage type & Primer*** & Primer sequence $\left(5^{\prime}-3^{\prime}\right) * *$ & $\begin{array}{l}\text { PCR product } \\
\text { length (bp) }\end{array}$ & Sequence coding for \\
\hline \multirow[t]{2}{*}{ 3A-like phage } & SGA1 & TATCAGGCGAGAATTAAGGG & 744 & Tail fibres \\
\hline & SGA2 & CTTTGACATGACATCCGCTTGAC & & \\
\hline \multirow[t]{2}{*}{ 11-like phage } & SGB1 & ACTTATCCAGGTGGYGTTATTG & 405 & Hypothetical tail protein \\
\hline & SGB2 & TGTATTTAATTTCGCCGTTAGTG & & \\
\hline \multirow[t]{6}{*}{ 77-like phage } & SGF1 & CGATGGACGGCTACACAGA & 155 & Hypothetical tail protein \\
\hline & SGF2 & TTGTTCAGAAACTTCCCAACCTG & & \\
\hline & SGFa1 & TACGGGAAAATATTCGGAAG & 548 & Packaging protein \\
\hline & SGFa2 & ATAATCCGCACCTCATTCCT & & \\
\hline & SGFb1 & AGACACATTAAGTCGCACGATAG & 147 & Packaging protein \\
\hline & $\mathrm{SGFb} 2$ & TCTTCTCTGGCACGGTCTCTT & & \\
\hline \multirow[t]{2}{*}{ 187-like phage } & SGL1 & GCTTAAAACAGTAACGGTGACAGTG & 648 & Hypothetical capsid protein \\
\hline & SGL2 & TGCTACATCATCAAGAACACCTGG & & \\
\hline \multirow[t]{2}{*}{ Twort-like phage } & SGD1 & TGGGCTTCATTCTACGGTGA & 331 & Major capsid protein \\
\hline & SGD2 & GTAATTTAATGAATCCACGAGAT & & \\
\hline
\end{tabular}

*S. aureus strain NCTC 8325 was used as positive control

**Nucleotide sequences were derived from the published sequences by Pantůček et al [31]

***The concentration of primers was $0.04 \mu \mathrm{mol}$ 
(8.4\%), S. equorum (6.5\%), S. saprophyticus (4.4\%), S. sciuri $(3.9 \%)$, S. hominis $(3.2 \%)$, S. xylosus $(3.2 \%)$, S. arlettae (2.4\%), S. simulans (1\%), S. felis $(0.9 \%)$, S. vitulinus $(0.9 \%)$, S. delphini (0.7\%), S. epidermidis $(0.7 \%)$, S. haemolyticus $(0.7 \%)$, S. condimenti $(0.5 \%)$, S. warneri $(0.5 \%)$, S. alactolyticus $(0.4 \%)$, S. carnosus $(0.4 \%), S$. capitis $(0.4 \%), S$. hyicus $(0.4 \%)$, S. lugdunensis $(0.4 \%)$, S. schleiferi subsp. coagulans $(0.4 \%)$.

PCR confirmed the presence of the nuc gene in all 85 (100\%) S. aureus strains.

\section{Prevalence of MRSA Strains}

PCR confirmed the presence of a $533 \mathrm{bp}$ product characteristic of the presence of the mecA gene in 26 (30.6\%) strains.

\section{Phenotypic Susceptibility of the Isolated Bacteria to Selected Antimicrobial Agents}

The minimum inhibitory concentration (MIC) against oxacillin showed that 24 isolates of $S$. aureus (28.2\%) were resistant to this antibiotic. All strains showing a MIC value indicating resistance to oxacillin also possessed the mecA gene.

As a result of the susceptibility testing of the isolated $S$. aureus strains to 11 selected antimicrobial agents, $100 \%$ susceptibility in in vitro conditions for cefoxitin was observed among of 59 MSSA strains. A relatively high percentage of MSSA strains were found to be susceptible to clindamycin (96.6\%), trimethoprim-sulphamethoxazole (96.6\%), chloramphenicol (93.3\%), amoxicillin + clavulanic acid (93.2\%) and amoxicillin (89.8\%). Considerably more MSSA isolates exhibited resistance to gentamicin $(18.6 \%)$ and tetracycline (28.8\%). Over half of the MSSA strains were resistant to the other three antimicrobial agents, with the highest percentage of strains, $68.3 \%$ resistant to penicillin G. Among MRSA isolates, $100 \%$ in vitro susceptibility was not observed in any of the eleven antimicrobial agent applied. All MRSA strains were resistant to penicillin $\mathrm{G}$ and ampicillin. A high percentage of strains were resistant to amoxicillin (96.2\%), cefoxitin $(85 \%)$, amoxicillin + clavulanic acid $(84.7 \%)$, tetracycline $(84.7 \%)$, erythromycin $(80.8 \%)$ and clindamycin $(73 \%)$. Detailed data are presented in Table 3.

\section{Prevalence of Toxin Genes in S. aureus and MRSA Isolates}

The results of the multiplex PCR for five classical enterotoxins (A-E) showed that the genome of one of the MRSA strains contained the gene responsible for the production of enterotoxin A. Four strains carried the gene responsible for the production of enterotoxin B and one strain contained the gene responsible for the production of enterotoxin D. None of the MRSA strains had genes responsible for the production of enterotoxins $\mathrm{C}$ and $\mathrm{E}$ (Table 4).

In the case of MSSA strains $(n=59)$, the presence of two strains capable of producing enterotoxin A was confirmed. Five strains showed the presence of the gene responsible for the production of enterotoxin B, two strains had genes responsible for the production of enterotoxin $\mathrm{C}$ and one strain had the gene responsible for the production of enterotoxin D. None of the MSSA strains carried the gene
Table 3 Phenotypic*, antimicrobial resistance of $S$ aureus strains isolated from broiler chickens and turkeys

\begin{tabular}{|c|c|c|c|c|c|c|}
\hline \multirow[t]{2}{*}{ Antibiotic } & \multicolumn{3}{|c|}{ MRSA strains $n=26$} & \multicolumn{3}{|c|}{ MSSA strains $n=59$} \\
\hline & $\mathrm{R}$ & I & $\begin{array}{l}\text { Resistance rate } \\
(\%)\end{array}$ & $\mathrm{R}$ & I & $\begin{array}{l}\text { Resistance } \\
\text { rate }(\%)\end{array}$ \\
\hline Amoxicillin & 23 & 2 & 96.2 & 5 & 1 & 10.2 \\
\hline Amoxicillin + clavulanic acid & 12 & 10 & 84.7 & 4 & - & 6.8 \\
\hline Ampicillin & 24 & 2 & 100 & 32 & - & 54.2 \\
\hline Penicillin G & 26 & - & 100 & 38 & 2 & 68.3 \\
\hline Cefoxitin & 22 & - & 85 & - & - & - \\
\hline Clindamycin & 14 & 5 & 73 & - & 2 & 3.4 \\
\hline Chloramphenicol & 6 & 1 & 26.9 & 1 & 3 & 6.7 \\
\hline Erythromycin & 17 & 4 & 80.8 & 31 & - & 52.5 \\
\hline Gentamicin & 5 & - & 19.2 & 10 & 1 & 18.6 \\
\hline Tetracycline & 20 & 2 & 84.7 & 11 & 6 & 28.8 \\
\hline Trimethoprim-sulphamethoxazole & 3 & 1 & 15.3 & 2 & - & 3.4 \\
\hline
\end{tabular}

The resistance rate was calculated as the number of intermediate and resistant isolates divided by the total number of isolates

$R$ resistant, $I$ intermediate

*The susceptibility o11 antibiotics was tested using standard disc diffusion method on Mueller-Hinton agar plates 
Table 4 Prophage content and prevalence of staphylokinase and toxins genes of the 26 MRSA S. aureus isolates estimated by multiplex PCR

\begin{tabular}{|c|c|c|c|c|c|c|c|}
\hline \multirow[t]{2}{*}{ Lysogenic type } & \multirow{2}{*}{$\begin{array}{l}\text { Number of MRSA } \\
\text { strains }(n=26)\end{array}$} & \multirow[t]{2}{*}{$(\%)$} & \multicolumn{4}{|c|}{ Presence of the gene } & \multirow[t]{2}{*}{ PFGE pulsotype } \\
\hline & & & $\begin{array}{l}\text { sea } \\
\text { seb } \\
\text { sec } \\
\text { sed } \\
\text { see }\end{array}$ & tst & $\begin{array}{l}e t a \\
e t b\end{array}$ & sak & \\
\hline \multicolumn{8}{|l|}{ Single lysogenic strains } \\
\hline 11-like (SGB) & 2 & 7.7 & - & - & - & - & A, a2 \\
\hline 77-like (SGFa) & 4 & 15.4 & - & - & - & 4 & $\mathrm{a} 1, \mathrm{a} 4, \mathrm{a} 5, \mathrm{a} 8$ \\
\hline 77-like (SGFb) & 4 & 15.4 & $\operatorname{seb}(n=1)$ & & & 2 & $\mathrm{a} 1, \mathrm{a} 2$ \\
\hline \multicolumn{8}{|l|}{ Double lysogenic strains } \\
\hline $3 \mathrm{~A}(\mathrm{SGA})-11(\mathrm{SGB})$ & 1 & 3.8 & - & - & - & - & $\mathrm{d}$ \\
\hline $3 \mathrm{~A}(\mathrm{SGA})-77 \mathrm{a}(\mathrm{SGFa})$ & 4 & 15.4 & $\begin{array}{l}\operatorname{sea}(n=1) \\
\operatorname{seb}(n=1)\end{array}$ & 1 & - & 2 & $\mathrm{a} 3, \mathrm{a} 11, \mathrm{a} 12, \mathrm{c}$ \\
\hline $11(\mathrm{SGB})-77 \mathrm{~b}(\mathrm{SGFb})$ & 2 & 7.7 & - & - & - & 1 & a1, a9 \\
\hline 77a (SGFa)—77b (SGFb) & 3 & 11.5 & $\operatorname{sed}(n=1)$ & & & 1 & a1, a6, a7 \\
\hline 77b (SGFb)—187 (SGL) & 1 & 3.8 & $\operatorname{seb}(n=1)$ & - & - & 1 & $\mathrm{~B}$ \\
\hline \multicolumn{8}{|l|}{ Triple lysogenic strains } \\
\hline $3 \mathrm{~A}(\mathrm{SGA})-11(\mathrm{SGB})-77 \mathrm{a}(\mathrm{SGFa})$ & 1 & 3.8 & - & - & - & - & $\mathrm{C}$ \\
\hline 3A (SGA-77a(SGFa)- 77b (SGFb) & 2 & 7.7 & $\operatorname{seb}(n=1)$ & - & - & 1 & $a 1, b$ \\
\hline $11(\mathrm{SGB})-77 \mathrm{a}(\mathrm{SGFa})-77 \mathrm{~b}(\mathrm{SGFb})$ & 2 & 7.7 & - & - & - & 1 & $\mathrm{a} 10, \mathrm{a} 13$ \\
\hline
\end{tabular}

MRSA methicillin-resistant S. aureus, sea, seb, sec, cec, see enterotoxin A,B,C,D,E, tst toxic shock syndrome toxin-1, eta, etb exfoliative toxins A, B, sak staphylokinase

responsible for the production of enterotoxin $\mathrm{E}$ (Table 5; Fig. 1 in supplementary materials).

Regarding TSST- 1 and exfoliative toxins A and B, only one MRSA strain and two MSSA strains showed the presence of the $t s t$ gene. None of the MRSA strains had genes responsible for the production of exfoliative toxins A and B, and only one of the MSSA strains had the eta gene (Tables 4, 5 and Fig. 3 in supplementary materials).

\section{Detection of the Staphylokinase (sak) Gene}

The presence of the sak gene was demonstrated in 13 strains of MRSA and in 5 strains of MSSA. Detailed data are shown in Tables 4 and 5.

\section{Prophage Pattern in S. aureus Strains}

Multiplex PCR successfully distinguished the prophage 3A-like (SGA), 11-like (SGB) and 77-like (SGF) serogroups, the 77-like a ( $\mathrm{SGFa)}$ and $\mathrm{b}(\mathrm{SGFb})$ subgroups and 187-like (SGL).

In our study, four serotypes and two subtypes of prophages were detected. Furthermore, all MRSA and MSSA isolates contained at least one prophage incorporated in their genome. A total of 11 prophage patterns were identified among MRSA strains and 13 prophage patterns among MSSA strains. The most prevalent prophage patterns or lysogenic types among MRSA isolates were single lysogenic 77-like (Fa subtype), 77-like (Fb subtype) and double lysogenic 3A-like-77-like (Fa subtype). Among MSSA isolates, the most prevalent prophage pattern was 11-like, followed by single lysogenic 77-like (Fb subgroup), double lysogenic 3A-like-11-like and 11-like-77-like (Fb subgroup); detailed data are presented in Tables 4 and 5 and Fig. 2 in supplementary materials. Prophages of the Twort type were not identified in any of the $85 \mathrm{~S}$. aureus strains tested, while prophage 187-like was identified in the genome of one of the MRSA strains.

\section{Pulsed-Field Gel Electrophoresis (PFGE)}

Only three of the MRSA isolates were digested by SmaI enzyme and belonged to three different pulsotypes named as A, B and C (Table 4 and Figs. 4, 5 in supplementary materials). However, all twenty-six MRSA isolates were typeable using the restriction enzyme ApaI. The macrorestriction profiles obtained, following enzyme ApaI digestion, are presented in Figs. 6, 7 and 8 in supplementary materials. Analysis of the phylogenetic relationship between twenty-three of MRSA strains distinguished 16 macrorestriction profiles following digestion with ApaI endonuclease. Six isolates belonging to the pulsotype a1 and three isolates belonging to the pulsotype a2 showed the same ApaI-PFGE patterns 
Table 5 Prophage content and prevalence of staphylokinase and toxins genes of the 59 MSSA S. aureus isolates estimated by multiplex PCR

\begin{tabular}{|c|c|c|c|c|c|c|c|}
\hline \multirow[t]{2}{*}{ Lysogenic type } & \multirow{2}{*}{$\begin{array}{l}\text { Number of MSSA strains }(n=59) \\
\text { with respective PCR pattern }\end{array}$} & \multirow[t]{2}{*}{$(\%)$} & \multicolumn{5}{|c|}{ Presence of the gene } \\
\hline & & & $\begin{array}{l}\text { sea } \\
\text { seb } \\
\text { sec } \\
\text { sed } \\
\text { see }\end{array}$ & tst & $\begin{array}{l}\text { eta } \\
\text { etb }\end{array}$ & sak & \\
\hline \multicolumn{8}{|l|}{ Single lysogenic strains } \\
\hline 3A-like (SGA) & 5 & 8.5 & sea $(n=1)$ & & & & \\
\hline 11-like (SGB) & 11 & 18.6 & & 1 & & & \\
\hline 77-like (SGFa) & 3 & 5.1 & & & & & \\
\hline 77-like (SGFb) & 7 & 11.9 & $\operatorname{seb}(n=1)$ & & & & \\
\hline \multicolumn{8}{|l|}{ Double lysogenic strains } \\
\hline $3 \mathrm{~A}(\mathrm{SGA})-11(\mathrm{SGB})$ & 7 & 11.9 & $\begin{array}{l}\operatorname{seb}(n=1) \\
\sec (n=1)\end{array}$ & & & & 1 \\
\hline $3 \mathrm{~A}(\mathrm{SGA})-77 \mathrm{a}(\mathrm{SGFa})$ & 2 & 3.4 & sea $(n=1)$ & & & & 1 \\
\hline $11(\mathrm{SGB})-77 \mathrm{~b}(\mathrm{SGFb})$ & 7 & 11.9 & $\operatorname{seb}(n=1)$ & & $\mathrm{A}(n=1)$ & & \\
\hline $11(\mathrm{SGB})-77 \mathrm{a}(\mathrm{SGFa})$ & 2 & 3.4 & & & & & \\
\hline 77a (SGFa)-77b (SGFb) & 4 & 6.8 & $\operatorname{sed}(n=1)$ & & & & \\
\hline \multicolumn{8}{|l|}{ Triple lysogenic strains } \\
\hline 3A (SGA)- 11 (SGB) -77a (SGFa) & 3 & 5 & & & & 2 & \\
\hline $3 \mathrm{~A}(\mathrm{SGA})-11(\mathrm{SGB})-77 \mathrm{~b}(\mathrm{SGFb})$ & 4 & 6.8 & & 1 & & & \\
\hline $11(\mathrm{SGB})-77 \mathrm{a}(\mathrm{SGFa})-77 \mathrm{~b}(\mathrm{SGFb})$ & 3 & 5 & $\operatorname{seb}(n=1)$ & & & & \\
\hline \multicolumn{8}{|l|}{ Quadruple lysogenic strains } \\
\hline $\begin{array}{l}\text { 3A-like (SGA)—11-like (SGB)—-77a } \\
\text { (SGFa)—77b (SGFb) }\end{array}$ & 1 & 1.7 & $\begin{array}{l}\operatorname{seb}(n=1) \\
\sec (n=1)\end{array}$ & & & 1 & \\
\hline
\end{tabular}

MSSA methicillin-sensitive S. aureus, sea, seb, sec, $c e c$, see enterotoxin A,B,C,D,E, tst toxic shock syndrome toxin-1, eta, etb exfoliative toxins A, B, sak staphylokinase

(Fig. 1). The genetic similarity of the remaining 14 MRSA strains ranged from 65 to $98 \%$ (Fig. 1).

\section{Discussion}

The threat of Staphylococcus aureus is due to its ease of transmission between animals and humans and its pathogenicity. It has been demonstrated that livestock-associated $S$. aureus strains (LA-MRSA) originated in humans and vice versa $[34,35]$. Here, we characterized the presence of a group of genes responsible for toxin production and methicillin resistance in S. aureus isolated from slaughter poultry. Determination of the oxacillin MIC is a method recommended by the CLSI for the detection of meticillin resistance in routine testing; however, some recent studies have reported low sensitivity and low specificity of oxacillin compared with cefoxitin [20]. Therefore, cefoxitin is considered to be a better predictor than oxacillin for the detection of heteroresistance because it is a stronger inducer of penicillin-binding protein 2a (PBP2a) [36, 37]. In our study, discrepancies between phenotypic oxacillin and cefoxitin susceptibility and the presence of mecA gene were observed for two and four isolates, respectively. The overall MRSA prevalence in this study was $30.6 \%$. Oxacillin-resistant $S$. aureus are considered resistant to other $\beta$-lactam agents, i.e. penicillins, $\beta$-lactam/ $\beta$-lactamase inhibitor combinations, cephems and carbapenems. This is because most cases of documented of MRSA infections have responded poorly to $\beta$-lactam therapy, or because convincing clinical data that document clinical efficacy for those agents have not been presented [20]. While all the MSSA strains tested in the present study were susceptible to cefoxitin and oxacillin, over half of them were found to be resistant to three antibiotics applied. Among the strains of MSSA, the most frequently observed resistance included lack of susceptibility to penicillin $\mathrm{G}$, ampicillin and erythromycin. The present study confirmed the presence of the mecA gene responsible for resistance to methicillin in twenty-six of the $S$. aureus strains which were all resistant to penicillin $\mathrm{G}$ and ampicillin (Table 3). Resistance to methicillin is heterogeneous, which can cause some difficulty in determining these characteristics under in vitro conditions, and may lead to complications in the preparation of the test and the interpretation of results [19]. The literature data indicate that most multi-resistant strains of Staphylococcus aureus exhibit a 


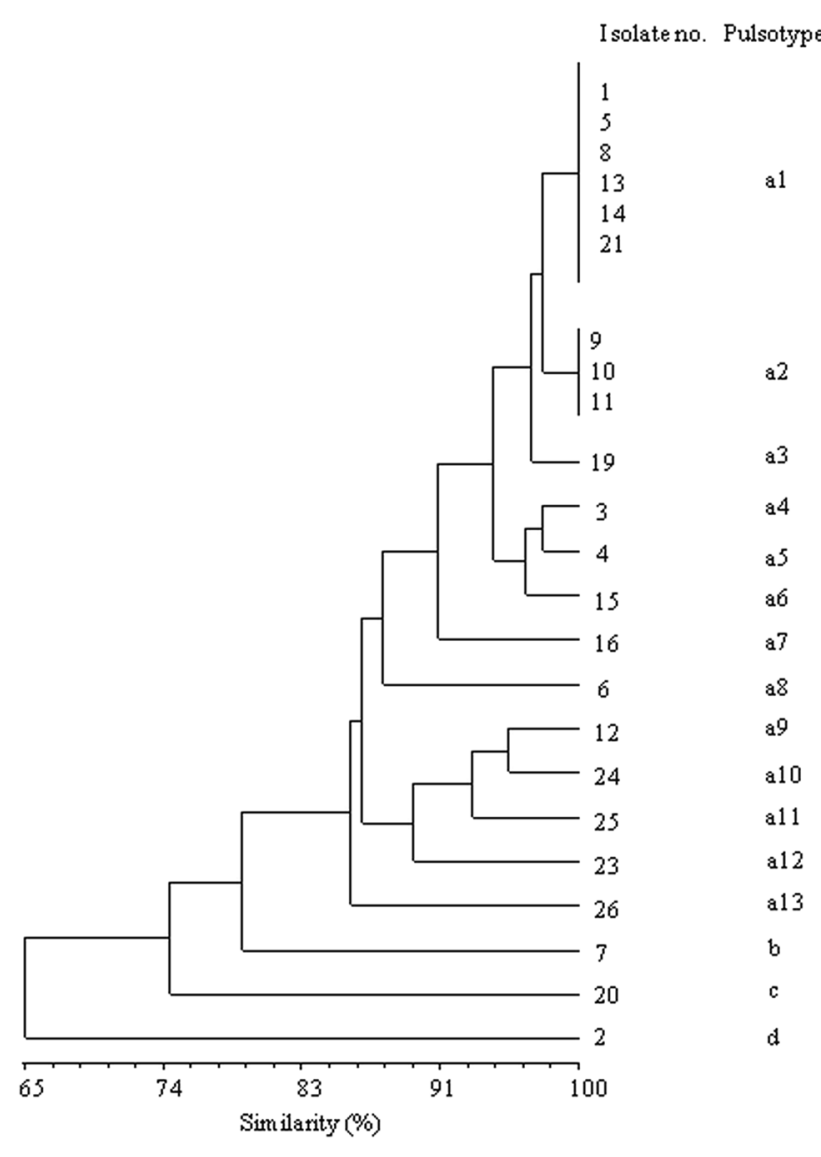

Fig. 1 Dendrogram showing genetic similarity among twenty-three MRSA isolates digested with ApaI restriction endonuclease

lack of susceptibility to erythromycin and tetracycline, and less often to gentamycin and chloramphenicol [38]. Moreover, MRSA strains are also considered to be resistant to all cephalosporins and other $\beta$-lactam antibiotics regardless of the results of tests conducted under in vitro conditions [20]. In our study, the most frequently observed resistance among MRSA strains included lack of susceptibility to penicillin G, ampicillin, amoxicillin, cefoxitin, amoxicillin + clavulanic acid, oxacillin and tetracycline. Over half of the tested strains also showed a lack of sensitivity to erythromycin and clindamycin. The rates of resistance of MRSA to chloramphenicol, gentamycin and trimethoprim-sulphamethoxazole were much lower $(<30 \%)$ than those to other antibiotics.

These data are disturbing, given the fact that $S$. aureus strains were isolated from poultry flocks located only in the area of central-western Poland. For comparison, in research conducted by Persoons et al. (2009) in Belgium, MRSA was isolated from 8 broiler chickens from two of the 14 farms sampled. In the MRSA-positive flocks, the number of positive samples varied between $1 / 5(20 \%)$ and 5/5 (100\%) [4]. However, data published in 2009 by de Boer et al. indicate that the highest prevalence of MRSA in poultry was in the Netherlands, where MRSA was isolated from $16.0 \%$ of chicken meat samples and $35.3 \%$ of retail turkey meat samples [17]. Most MRSA isolates have been shown to be resistant to several classes of antibiotics and more than $80 \%$ of them produce penicillinases [19]. The research conducted on poultry farms indicate that the farm staff is exposed to an increased risk of MRSA colonization compared to the general population [39]. The results of the study published by Richter et al. indicate that the prevalence of MRSA in the investigated turkey meat production farms in the southwest of Germany reached $90 \%$. In addition, among these isolates, the majority were livestock-associated MRSA [40].

Bacteriophages play an important role in the biology of S. aureus. Through horizontal gene transfer and lysogenic phage conversion associated with virulence factors, they can convert a non-virulent strain of staphylococcus into a virulent one [1, 19, 41]. Interestingly, the toxins of the superantigens are detected more often among methicillin-resistant staphylococci. For example, enterotoxin A is more commonly produced by MRSA strains [42]. The use of $\beta$-lactam antibiotics and fluoroquinolones in sub-inhibitory concentrations has been shown to induce the emergence of prophages from latent states. This results in the replication of the viral genome and the amplification of the genes encoded therein, including lysogenic conversion genes [12, 43].

The results of our study indicated a high prevalence of prophages among the test isolates of $S$. aureus. In all, 15 prophage patterns were observed among the isolates. The most prevalent prophage patterns or lysogenic types among MRSA isolates were single lysogenic 77-like, while among MSSA isolates the most prevalent prophage pattern was 11-like. The prophages detected least frequently were 3A-like (SGA) (5.8\%) and 187-like (SGL) (3.8\%) (Tables 4, 5). Similar results have been obtained by other authors, who studied the types of bacteriophages presented in human methicillin-resistant $S$. aureus strains [44]. However, the most prevalent prophage type detected in the genome of human MRSA strains by Pantůček et al. was 3A-like [31]. The difference may be due to the fact that the microorganisms were isolated in different geographic locations and from different animal species.

The results of our study indicate that as many as 18 (13 MRSA and 5 MSSA) of the strains tested had the sak gene responsible for the production of staphylokinase. Some authors believe that the activity of phage-encoded virulence factors such as staphylokinase is specific for human target molecules, indicating tight host/pathogen coevolution [45]. Matthews and Novick suggest that strains of bovine origin carry sak-containing phages less frequently than human isolates [46]. Our knowledge about prophage patterns in $S$ aureus of poultry origin is poorly known. There have been reports suggesting that serogroup F (77-likevirus) and B (11-likevirus) phages of Staphylococcus aureus are capable 
of expressing staphylokinase [31, 47, 48,]. The results of our study indicate that most of the $S$. aureus strains that possessed the sak gene also had 77-like prophages incorporated into their genome.

As well as its importance as a livestock and communityassociated pathogen, $S$. aureus is also a well-known cause of food intoxication $[2,3,8,49]$. It is estimated that the actual number of foodborne illnesses caused by $S$. aureus is much higher than those reported [30]. The relationship between the production of enterotoxin $\mathrm{A}$ and the presence of bacteriophages and the enterotoxin A (sea) gene in the DNA of temperate bacteriophages was first described by Betley et al. [10]. Coleman et al. showed that, depending on the phenotype observed in lysogenic cells, bacteriophages converting enterotoxin A can simultaneously convert staphylokinase $[16,25]$. Among the $S$. aureus strains tested, the presence of the sea gene was found in three strains (one MRSA and two MSSA), two of which also had the sak gene. Interestingly, strains with both the sea and sak genes had the same prophage pattern (3A-77a) (Tables 4, 5). A relationship between the production of other toxins (toxic shock syndrome and exfoliative toxins) and the presence of prophages in the genome of $S$. aureus bacteria has also been demonstrated [8]. In research conducted by El-Adawy et al. (2016), the genes encoding the toxic shock syndrome toxin $(t s t), s e a, s e b, s e c$ and see, and genes for exfoliative toxins (etaletb) were not found in any turkey and broiler chicken isolates [50]. In our study, the presence of genes (tst- 1 ) was detected in three of the 85 strains tested, while only one strain had the gene responsible for producing exfoliatin A (eta). The MRSA strain that possessed the $t s t-1$ gene had the 3A-77a prophage pattern, while the other two MSSA strains had prophage patterns 11-like and 3A-11-77b. In contrast, the MSSA strain in which the exfoliatin A gene was detected had prophage pattern 11-77b (Tables 4, 5).

The results are particularly disturbing given that exfoliative toxins (ETs) produced by $S$. aureus strains are the major causative agents of blistering skin disorders in humans. Literature data indicate that staphylococcal scaled-skin syndrome (SSSS) caused by antibiotic-resistant strains of $S$. aureus has recently emerged as a serious problem [5].

The toxic shock syndrome toxin 1 (tst-1) gene is located within mobile genetic element such as staphylococcal SaP11 pathogenicity island, which by horizontal transfer can occur through bacteriophage transduction. Studies conducted on strains of $S$. aureus isolated from healthy humans showed that a significant percentage of isolates $(24.3 \%)$ possessed the gene for TSST-1 [23]. Therefore, it is believed that many healthy individuals carry toxin-producing strains of $S$. aureus. Some pathogenicity islands of $S$. aureus can be transduced to other staphylococcal species: S. chromogenes, S. intermedius, S. xylosus and S. epidermidis [46]. The transfer of the SaPI1 pathogenicity island associated with prophage induction from the cells of $S$. aureus into Listeria monocytogenes has been observed as well, having spontaneously occurred in cow's milk [11].

Pulsed-field gel electrophoresis (PFGE) is the most applied and effective genetic typing method for epidemiological studies and investigation of foodborne outbreaks caused by different pathogens, including Staphylococcus aureus. Traditionally, human MRSA isolates have been typed by pulsed-field gel electrophoresis (PFGE), using SmaI as the restriction enzyme [51]. The advantages of using PFGE are good discriminatory power and good reproducibility at the interlaboratory level when standardized protocols are used. It is possible that livestock-associated MRSA (LA-MRSA) is not typeable by this method, as the activity of $S m a \mathrm{I}$ is blocked due to methylation of the restriction site [52]. In our study, only three of the MRSA isolate was typeable by $S m a$ I enzyme digestion. The remaining twenty-three isolates were typeable using the restriction enzyme ApaI, an alternative to $S m a \mathrm{I}$ as mentioned above. It is likely that the twentythree MRSA isolates that have not been digested by the SmaI enzyme and have been digested with the ApaI enzyme are of animal origin. Similar observations were made by Bens et al. (2006) when examining their isolates collected at a pig farm [52].

DNA restriction analysis using $A p a \mathrm{I}$ as the restriction enzyme revealed sixteen different patterns, which means that in the case of MRSA there were six and three identical strains with the same macrorestriction profiles (Fig. 1). This may suggest a cross infection by these bacteria in different individuals within the poultry flock.

\section{Conclusions}

We confirmed the presence of $30,6 \%$ positive strains of MRSA in food production animals (chickens and turkeys), which as livestock are in close contact with humans (farmers, farm co-workers, veterinarians). The results strongly suggest that people working with livestock are at a potential risk of becoming MRSA carriers and hence at an increased risk of infections caused by MRSA. This might complicate MRSA control measures in human healthcare, urging research into risk factors and transmission routes. Also, the relative high frequency of some virulence genes in strains of S. aureus originated from slaughtered poultry in this study may reflect the potential hazard to consumers.

The $S$. aureus strains we studied harboured at least one or up to three prophages. In consequence, high diversity among prophages results in the high potential of the isolate to produce a wide range of virulence factors. In our studies, the presence of 77-like prophages incorporated into bacterial genome was especially often demonstrated. Various authors emphasize the special role of these prophages in the spread 
of virulence factors (staphylokinase, enterotoxin A) between Staphylococcus strains $[31,48]$. From the point of view of human medicine as well as veterinary medicine, it is also particularly disturbing that $S$. aureus virulence factors can be transferred via mobile genetic elements not only within strains of the same species but also between species and even types of bacteria.

Acknowledgements This research did not receive any specific grant from finding agencies in the public, commercial or not for profit sectors.

\section{Compliance with Ethical Standards}

Conflict of interest The authors have no conflicts of interest to declare.

Open Access This article is distributed under the terms of the Creative Commons Attribution 4.0 International License (http://creativeco mmons.org/licenses/by/4.0/), which permits unrestricted use, distribution, and reproduction in any medium, provided you give appropriate credit to the original author(s) and the source, provide a link to the Creative Commons license, and indicate if changes were made.

\section{References}

1. Baba T, Takeuchi F, Kuroda M, Yuzawa H, Aoki K, Oguchi A, Nagai Y, Iwama N, Asano K, Naimi T, Kuroda H, Cui L, Yamamoto K, Hiramatsu K (2002) Genome and virulence determinants of highly virulence community-acquired MRSA. Lancet 359:1819-1827

2. Baba-Moussa L, Ahissou H, Azokpota P, Assogba B, Atindéhou MM, Anagonou S, Keller D, Sanni A, Prévost G (2010) Toxins and adhesion factors associated with Staphylococcus aureus strains isolated from diarrheal patient in Benin. Afr J Biotechnol 9:604-611

3. de Buyser ML, Dilasser F, Hummel R, Bergdoll MS (1987) Enterotoxin and toxic shock syndrome toxin-1 production by staphylococci isolated from goat's milk. Int J Food Microbiol 5:301-309

4. Persoons D, Van Hoorebeke S, Hermans K, Butaye P, de Kruif A, Haesebrouck F, Dewulf J (2009) Methicillin-resistant Staphylococcus aureus in poultry. Emerg Infect Dis 15:452-453

5. Yamasaki O, Yamaguchi T, Sugai M, Chapuis-Cellier C, Arnaud F, Vandenesch F, Etienne J, Lina G (2005) Clinical manifestations of Staphylococcal scaled-skin syndrome dependent on serotypes of exfoliative toxins. J Clin Microbiol 43:1890-1893

6. Dinges MM, Orwin PM, Schlievert PM (2000) Exotoxins of Staphylococcus aureus. Clin Microbiol Rev 13:16-34

7. Rooijakkers SH, van Kessel KP, van Strijp JA (2005) Staphylococcal innate immune evasion. Trends Microbiol 13:596-601

8. Argudin MA, Mendoza MC, Rodicio MR (2010) Food poisoning and Staphylococcus aureus enterotoxins. Toxins 2:1751-1773

9. Schlievert PM (1993) Role of superantigens in human diseases. J Infect Dis 167:997-1002

10. Betley MJ, Mekalanos JJ (1988) Nucleotide sequence of the type A staphylococcal enterotoxin gene. J Bacteriol 170:34-41

11. Chen J, Novick RP (2009) Phage-mediated intergeneric transfer of toxin genes. Sciences 323:139-141

12. Łoś JM, Łoś M, Węgrzyn G (2011) Bacteriophages carrying shiga toxin genes: genomic variations, detection and potential treatment of pathogenic bacteria. Future Microbioly 6:909-924
13. Malachowa N, DeLeo FR (2010) Mobile genetic elements of Staphylococcus aureus. Cell Mol Life Sci 67:3057-3071

14. Doskar J, Pallová P, Pantůcek R, Rosypal S, Růzicková V, Pantůcková P, Kailerová J, Klepárník K, Malá Z, Bocek P (2000) Genomic relatedness of Staphylococcus aureus phages of the International Typing Set and detection of serogroup A, B, and F prophages in lysogenic strains. Can J Microbiol 46:1066-1076

15. Ackermann HW, DuBow MS (1987) Viruses of prokaryotes, vol 2. Natural groups of bacteriophages. CRC Press, Boca Raton

16. Coleman DC, Sullivan D, Russell RJ (1989) Staphylococcus aureus bacteriophages mediating the simultaneous lysogenic conversion of $\beta$-lysin, staphylokinase and enterotoxin A: molecular mechanism of triple conversion. J Gen Microbiol 135:1679-1697

17. de Boer E, Zwartkruis-Nahuis JT, Wit B, Huijsdens XW, de Neeling AJ, Bosch T, van Oosterom RA, Vila A, Heuvelink AE (2009) Prevalence of methicillin-resistant Staphylococcus aureus in meat. Int J Food Microbiol 134:52-56

18. Murakami K, Minamide W, Wada K, Nakamura E, Teraoka H, Watanabe S (1991) Identification of methicillin-resistant strains of staphylococci by polymerase chain reaction. J Clin Microbiol 29:2240-2244

19. Chambers HF (1997) Methicillin resistance in Staphylococci: Molecular and biochemical basis and clinical implications. Clin Microbiol Rev 10:781-791

20. Clinical and Laboratory Standards Institute (2015) Performance Standards for Antimicrobial Susceptibility Testing; Twenty-Fifth Informational Supplement. CLSI document M100-S25. Wayne PA 35: 64-72

21. Marek A, Stępień-Pyśniak D, Pyzik E, Adaszek Ł, Wilczyński J, Winiarczyk S (2016) Occurrence and characterization of Staphylococcus bacteria isolated from poultry in Western Poland. Berl Munch Tierarztl Wochenschr 129:147-152

22. Brakstad OG, Aasbakk K, Maeland JA (1992) Detection of Staphylococcus aureus by polymerase chain reaction amplification of the nuc gene. J Clin Microbiol 30:1654-1660

23. Mehrotra M, Wang G, Johnson WM (2000) Multiplex PCR for detection of genes for Staphylococcus aureus enterotoxins, exfoliative toxins, toxic shock syndrome toxin 1 , and methicillin resistance. J Clin Microbiol 38:1032-1035

24. Sung JML, Lloyd DH, Lindsay JA (2008) Staphylococcus aureus host specificity: comparative genomics of human versus animal isolates by multi-strain microarray. Microbiology 154:1949-1959

25. Cremonesi P, Perez G, Pisoni G, Moroni P, Morandi S, Luzzana M, Brasca M, Castiglioni B (2007) Detection of enterotoxigenic Staphylococcus aureus isolates in raw milk cheese. Lett Appl Microbiol 45:586-591

26. Bayles KW, Iandolo JJ (1989) Genetic and molecular analyses of the gene encoding staphylococcal enterotoxin D. J Bacteriol 171:4799-4806

27. Bystroń J, Molenda J, Bania J, Kosek-Paszkowska K, Czerw M (2005) Occurrence of enterotoxigenic strains of Staphylococcus aureus in raw poultry meat". Pol J Vet Sci 8:37-40

28. Blomster-Hautamaa DA, Kreiswirth BN, Kornblum JS, Novick RP, Schlievert PM (1986) The nucleotide and partial amino acid sequence of toxic shock syndrome toxin-1. J Biol Chem 261:15783-15786

29. Lee CY, Schmidt JJ, Johnson-Winegar AD, Spero L, Iandolo JJ (1987) Sequence determination and comparison of the exfoliative toxin A and toxin B genes from Staphylococcus aureus. J Bacteriol 169:3904-3909

30. Mead PS, Slutsker L, Dietz V, McCaig LF, Bresee JS, Shapiro C, Griffin MF, Tauxe RF (1999) Food-related illness and death in the United States. Emerg Infect Dis 5:607-625

31. Pantůček R, Doškař J, Růžičková V, Kašpárek P, Oráčová E, Kvardová V, Rosypal S (2004) Identification of bacteriophage 
types and their carriage in Staphylococcus aureus. Arch Virol 149:1689-1670

32. Hauschild T, Schwarz S (2003) Differentiation of Staphylococcus sciuri strains isolated from free-living rodents and insectivores. $\mathrm{J}$ Vet Med B 50::241-246

33. Tenover FC, Arbeit RD, Goering RV, Mickelsen PA, Murray BE, Persing DH, Swaminathan B (1995) Interpreting chromosomal DNA restriction patterns produced by pulsed-field gel electrophoresis: criteria for bacterial strain typing. J Clin Microbiol 33:2233-2239

34. Resch G, François P, Morisset D, Stojanov M, Bonetti EJ, Schrenzel J, Sakwinska O, Moreillon P (2013) Human-to-bovine jump of Staphylococcus aureus CC8 is associated with the loss of a beta-hemolysin converting prophage and the acquisition of a new staphylococcal cassette chromosome. PLoS One 8:e58187

35. Stępień-Pyśniak D, Marek A, Rzedzicki J (2009) Occurrence of bacteria of the genus Staphylococcus in table eggs descended from different sources. Pol J Vet Sci 12:481-484

36. Cauwelier B, Gordts B, Descheemaecker P, Van Landuyt H (2004) Evaluation of a disk diffusion method with cefoxitin $(30 \mathrm{mg})$ for detection of methicillin-resistant Staphylococcus aureus. Eur J Clin Microbiol Infect Dis 23:389-392

37. Felten A, Grandry B, Lagrange PH, Casin I (2002) Evaluation of three techniques for detection of low-level methicillin-resistant Staphylococcus aureus (MRSA): a disk diffusion method with cefoxitin and moxalactam, the Vitek 2 system, and the MRSAscreen latex agglutination test. J Clin Microbiol 40:2766-2771

38. Lyon BR, Skurray R (1987) Antimicrobial resistance of Staphylococcus aureus: 309 Genetic basis. Microbiol Rev 51:88-135

39. Nemati M, Hermans K, Lipinska U, Denis O, Deplano A, Struelens M, Devriese LA, Pasmans F, Haesebrouck F (2008) Antimicrobial resistance of old and recent Staphylococcus aureus isolates from poultry: first detection of livestock-associated methicillin-resistant strain ST398. Antimicrob Agents Chemother 52:3817-3819

40. Richter A, Sting R, Popp C, Rau J, Tenhagen BA, Guerra B, Hafez HM, Fetsch A (2012) Prevalence of types of methicillin-resistant Staphylococcus aureus in turkey flocks and personnel attending the animals. Epidemiol Infect 140:2223-2232

41. Yoshizawa Y, Sakurada J, Sakurai S, Machida K, Kondo I, Masuda S (2000) An exfoliative toxin A-converting phage isolated from Staphylococcus aureus strain ZM. Microbiol Immunol 44:189-191

42. Kim JS, Song W, Kim HS, Cho HC, Lee KM, Choi MS, Kim EC (2006) Association between the methicillin resistance of clinical isolates of Staphylococcus aureus, their staphylococcal cassette chromosome mec (SCCmec), subtype classification, and their toxin gene profiles. Diagn Microbiol Infect Dis 56:289-295

43. Goerke C, Koller J, Wolz C (2006) Ciprofloxacin and trimethoprim cause phage induction and virulence modulation in Staphylococcus aureus. Antimicrob Agents Chemother 50:171-177

44. Rahimi F, Bouzari M, Katouli M, Pourshafie MR (2013) Prophage typing of methicillin resistant Staphylococcus aureus isolated from a Tertiary Care Hospital in Teheran, Iran. Jundishapur J Microbiol 6:80-85

45. Goerke C, Wirtz C, Flückiger U, Wolz C (2006) Extensive phage dynamics in Staphylococcus aureus contributes to adaptation to the human host during infection. Mol Microbiol 61:1673-1685

46. Matthews AM, Novick RP (2005) Staphylococcal phages in Phages. Their role in bacterial pathogenesis and biotechnology. Waldor MK, Friedman DI, Adhya SL (eds). Washington, DC: American Society for Microbiology Press, pp 297-318

47. Ko KS, Lee JY, Song JH, Baek JY, Oh WS, Chun J, Yoon HS (2006) Screening of essential genes in Staphylococcus aureus N315 using comparative genomics and allelic replacement mutagenesis. J Microbiol Biotechnol 16:623-632

48. Kondo I, Itoh S, Yoshizawa Y (1981) Staphylococcal phages mediating the lysogenic conversion of staphylokinase. In: Jeliaszewicz J (ed) Staphylococci and staphylococcal infections. Gustav Fisher Verlag, Stuttgart, pp 357-362

49. Bergdoll MS (1990) Staphylococcal food poisoning. In: Cliver DO (ed) Foodborne Diseases. Academic Press, San Diego, pp 85-106

50. El-Adawy H, Ahmed M, Hotzel H, Monecke S, Schulz J, Hartung J, Ehricht R, Neubauer H, Hafez M (2016) Characterization of Methicillin-resistant Staphylococcus aureus isolated from healthy turkeys and broilers using DNA microarrays. Front Microbiol. https://doi.org/10.3389/fmicb.2016.02019

51. Murchan S, Kaufmann ME, Deplano A, de Ryck R, Struelens M, Zinn CE, Fussing V, Salmenlinna S, Vuopio-Varkila J, El Solh N, Cuny C, Witte W, Tassios PT, Legakis N, van Leeuwen W, van Belkum A, Vindel A, Laconcha I, Garaizar J, Haeggman S, Olsson-Liljequist B, Ransjo U, Coombes G, Cookson B (2003) Harmonization of pulsed-field gel electrophoresis protocols for epidemiological typing of strains of methicillin-resistant Staphylococcus aureus: a single approach developed by consensus in 10 European laboratories and its application for tracing the spread of related strains. J Clin Microbiol 41:1574-1585

52. Bens CPM, Voss A, Klaassen CHW (2006) Presence of a novel DNA methylation enzyme in methicillin-resistant Staphylococcus aureus isolates associated with pig farming leads to uninterpretable results in standard pulsed-field gel electrophoresis analysis. J Clin Microbiol 44:1875-1876 